Final version available at http://www.sciencedirect.com/science/article/pii/S0033589409001112

\title{
The last interglacial sea-level high stand on the southern Cape Coastline of South Africa
}

\section{Andrew S. Carr ${ }^{\text {a }}$, Mark D. Bateman ${ }^{\text {b }}$, David L. Roberts ${ }^{\text {c }}$, Colin V. Murray-Wallace ${ }^{\text {d }}$} Zenobia Jacobs ${ }^{\mathrm{d}}$ and Peter J. Holmes ${ }^{\mathrm{e} .}$

${ }^{a}$ Department of Geography, University of Leicester University Road, Leicester LE1 7RH

${ }^{b}$ Sheffield Centre for International Drylands Research, Department of Geography, University of Sheffield, Winter Street, Sheffield, S10 2TN, UK.

${ }^{c}$ Council for Geoscience, PO Box 572, Bellville 7535, South Africa

${ }^{d}$ GeoQuEST Research Centre, School of Earth and Environmental Sciences, University of Wollongong, NSW, 2522, Australia

${ }^{e}$ Department of Geography, University of the Free State, PO Box 339, Bloemfontein 9300, South Africa 
Final version available at http://www.sciencedirect.com/science/article/pii/S0033589409001112

\section{Abstract} The continental margin of southern South Africa exhibits an array of emergent marginal marine

22 sediments permitting the reconstruction of long-term eustatic sea-level changes. We report a

23 suite of optical luminescence ages and supplementary amino acid racemization data, which

24 provide paleosea-level index points for three sites on this coastline. Deposits in the Swartvlei and

25 Groot Brak estuaries display tidal inlet facies overlain by shoreface or eolian facies.

26 Contemporary facies relations suggest a probable high stand 6.0-8.5 m above modern sea level

27 (amsl). At Cape Agulhas, evidence of a past sea-level high stand comprises a gravel beach (ca.

$283.8 \mathrm{~m}$ amsl) and an overlying sandy shoreface facies (up to $7.5 \mathrm{~m}$ amsl). OSL ages between 138

$29 \pm 7 \mathrm{ka}$ and $118 \pm 7 \mathrm{ka}$ confirm a last interglacial age for all marginal marine facies. The high

30 stand was followed by a sea-level regression associated with the accumulation of eolian dunes

31 dating to $122 \pm 7 \mathrm{ka}$ to $113 \pm 6 \mathrm{ka}$. These data provide the first rigorous numerical age

32 constraints for last interglacial sea-level fluctuations in this region, revealing the timing and

33 elevation of the last interglacial high stand to broadly mirror a number of other far-field

34 locations. 
Final version available at http://www.sciencedirect.com/science/article/pii/S0033589409001112

\section{Introduction}

The importance of constraining the timing and amplitudes of past sea-level changes has long been recognized (Bard et al., 1990; Stirling et al., 1995; Lambeck and Chappell, 2001;

Lambeck et al., 2002; Murray-Wallace, 2002; Muhs et al., 2004). In situations where eustatic sea-level change is the main driver of relative sea level, sea-level high stands (henceforth "high stands") can provide important information on changes in polar ice mass and help establish the duration of past interglacials (Gallup et al., 2002: Muhs, 2002). The major Southern Hemisphere landmasses (so-called "far-field" locations) are important for understanding sea-level changes as they have been relatively unaffected by the glacio-hydro-isostatic processes associated with close proximity to waxing and waning ice sheets (Fleming et al., 1998; Bassett et al 2006). They therefore offer the opportunity to reconstruct long-term eustatic and hydro-isostatic sea-level fluctuations where tectonic stability can also be demonstrated (Murray-Wallace, 2002; Woodroffe and Horton, 2005).

Past sea-level high stands have been investigated in various Southern Hemisphere locations (Young et al., 1993; Woodroffe et al., 1995; Stirling et al., 1998; Murray-Wallace, 2002; Tomazelli and Dillenburg, 2007; Hearty et al., 2007; O’Leary et al., 2008). The trailingedge continental margin of southern South Africa (Figure 1) also exhibits an array of marginal marine deposits and associated eolian dune deposits, but most sites currently lack numerical age control. South Africa is a far-field location and the southern Cape coastline is thought to have experienced limited Pleistocene tectonic activity (Goedhart, 2007). As such, emergent evidence of sea-level high stands can provide useful information regarding eustatic sea-level changes and should only be complicated by hydro-isostatic effects (Fleming et al., 1998; Woodroffe and Horton, 2005; Compton, 2001; 2006). Such data also serve to improve our understanding of the 
60 duration of previous interglacial intervals in the southern African context and are relevant to on-

61 going studies at important Middle Stone Age archaeological sites along this coastline (Marean et 62 al. 2007).

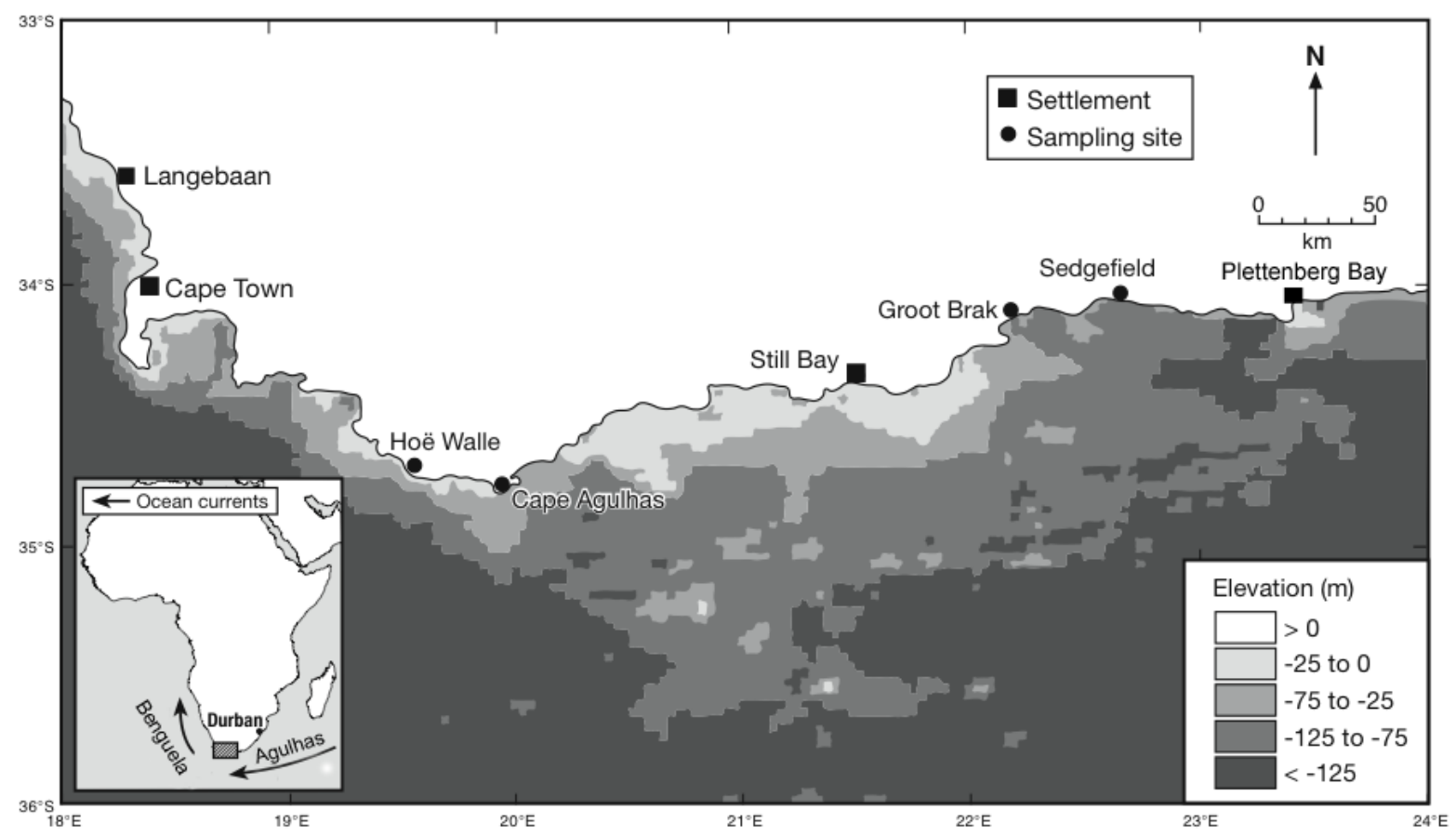

64 Figure 1: The Southern Cape coastline and continental shelf topography. Sample sites and other sites discussed in

65 the text are marked. Topographic and bathymetric data were derived from the ETOPO v2.2 dataset (U.S.

66 Department of Commerce, 2006) with -125 m representing the approximate last glacial maximum shoreline

The nature and timing of Pleistocene high stands in southern Africa remains contested

69 (Hendy and Volman 1986; Ramsay and Cooper, 2002; Bateman et al., 2004; Butzer, 2004).

70 Several workers have reported evidence for "marine platforms and terraces", which have been

71 identified at various altitudes including $12 \mathrm{~m}, 8 \mathrm{~m}, 4.5 \mathrm{~m}, 2.4 \mathrm{~m}, 1.4 \mathrm{~m}$, and $1 \mathrm{~m}$ above modern

72 sea level (amsl) (Maud 1968), 7-8 m, 4-5 m and 1-2 m amsl (Martin, 1962), 6.3 and 2-3 m amsl

73 (Tankard, 1976), and 12-15, 6-8 and $3 \mathrm{~m}$ amsl (Marker, 1987). Such erosional features are,

74 however, extremely difficult to date. A range of emergent marginal marine deposits, for which 
Final version available at http://www.sciencedirect.com/science/article/pii/S0033589409001112

75 geochronological data can now be obtained using luminescence dating techniques, have also

76 been described (e.g., Martin, 1962; Maud 1968; Tankard 1976; Cooper and Flores, 1991; Roberts

77 and Berger, 1997).

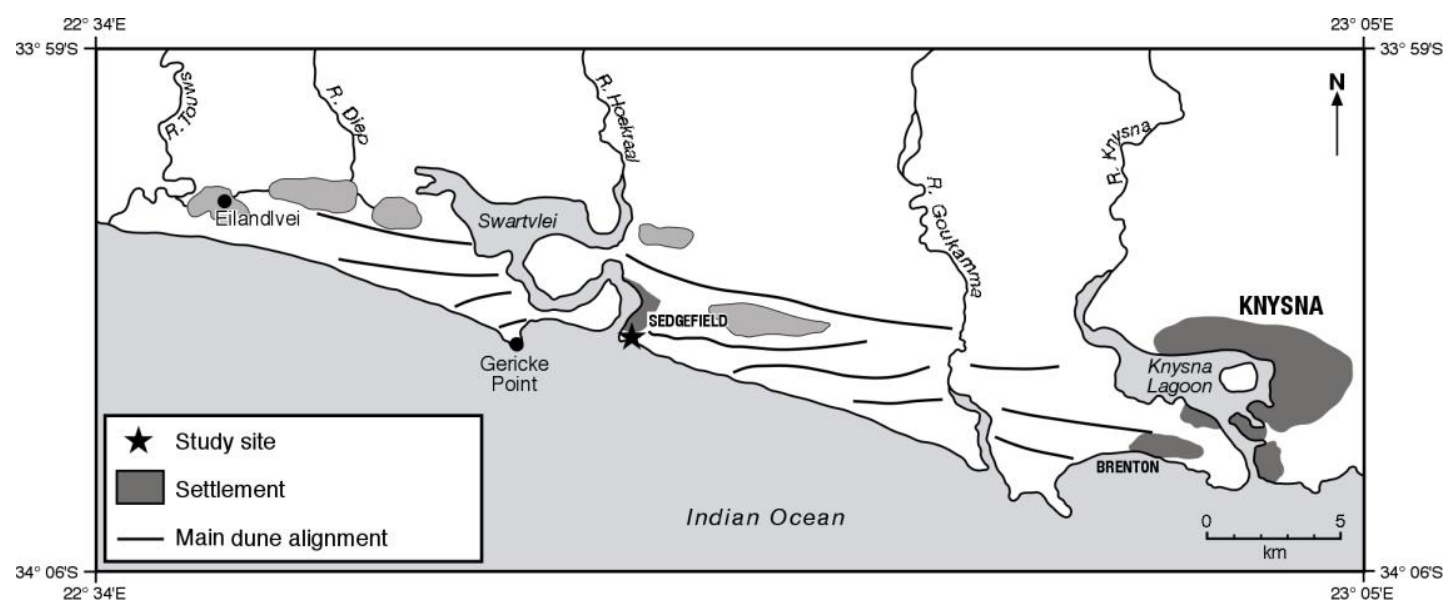

79 Figure 2: The Wilderness Embayment region, showing the Swartvlei Estuary at Sedgefield and the sampling

80 location

82 At present, chronological control at most sites, whether erosional or depositional in nature,

83 remains weak or lacking (e.g., Hendey and Volman, 1985). Ramsay and Cooper (2002)

84 presented a discontinuous sea-level curve for South Africa spanning the period $180 \mathrm{ka}$ to the

85 present. Data associated with Marine Isotope Stages (MIS) 5e-5a comprised four uranium-series

86 (U-series) ages in the range 130-100 ka. The uncertainties associated with these ages were

87 variable and large (e.g. $112 \pm 23 \mathrm{ka}$; Pta U415), but they were inferred to post-date MIS 5e (130-

$88116 \mathrm{ka}$; Kukla, 2000). This was ascribed to reworking during an MIS 5c high stand (ca. 106-95

89 ka), which was comparable in magnitude (ca. $4 \mathrm{~m}$ amsl) to MIS 5e. Such data are inconsistent

90 with other estimates of eustatic sea levels at these times (e.g., Cutler et al., 2003) and the benthic

91 oxygen isotope record (Martinson et al., 1987). They were derived via ${ }^{230} \mathrm{Th} /{ }^{234} \mathrm{U}$ dating of single

92 mollusk shells; an approach that has been reported to suffer the effects of open-system behavior 
Final version available at http://www.sciencedirect.com/science/article/pii/S0033589409001112

93 regarding uranium uptake history (Kaufman et al., 1971; McLaren and Rowe, 1996).

94 Furthermore, mollusks do not precipitate dissolved uranium directly from sea water (Muhs et al.,

95 2004). A fuller suite of dated sea-level high stand indicators is therefore needed to provide a

96 more rigorous consideration of the amplitude and timing of the MIS 5 high stand(s) along the

97 South African coast.

98 The main objective of this study is to refine and extend the South African record of late

99 Quaternary sea-level change through the application of optically stimulated luminescence (OSL)

100 dating at key exposures of raised marginal marine and associated eolian facies. A limited

101 number of amino acid racemization (AAR) analyses provide supplementary relative age

102 constraints. We interpret the resulting ages and amplitudes of paleosea-level fluctuations in

103 relation to the regional coastal geomorphic record and other far-field and eustatic sea-level

104 records.

105

106 Materials and Methods

107 We sampled four sites along $300 \mathrm{~km}$ of the southern Cape coastline where marginal

108 marine and/or associated eolian sediments are exposed above present sea level (Figure 1).

109 Lithology, paleoflow / paleowind patterns and paleontology were used to define the component

110 sedimentary facies. The spatial relationships among the various modern facies were used to

111 derive the depositional setting within the sedimentary record. This permitted the identification of

112 sea-level index points; that is, points of known age, elevation and sea-level tendency (i.e., sea

113 level rising or falling). For each index point the "indicative meaning" is an interpretation of the

114 vertical relationship between the depositional environment of the index point and the

115 contemporaneous mean sea level (Woodroffe and Horton, 2005). The "indicative range" gives an 
Final version available at http://www.sciencedirect.com/science/article/pii/S0033589409001112

116 estimated vertical uncertainty in sea level associated with the index point (Ferranti et al., 2006;

117 Woodroffe and Horton, 2005). Although offering the opportunity to apply techniques such as

118 luminescence dating, index points based on beach and foreshore deposits are typically associated

119 with relatively wide indicative ranges (Short, 1984; Ferranti et al., 2006). Elevations of the

120 identified facies and paleosea-level index points relative to modern sea level were obtained via

121 leveling. It is also assumed that past tidal ranges were comparable to the present (i.e., micro-

122 tidal, with a maximum spring range of 1.5-2.0 m; Cooper, 2001).

\section{Sedimentological analyses}

125 Analyses of particle size distribution and calcium carbonate percentage, as well as dry

126 color description, were undertaken (Siesser and Rogers, 1970; Tucker, 1988; Non-affiliated Soil

127 Analysis Working Committee, 1990; Munsell Color, 1994). Particle-size distributions were

128 determined using a settling column. This column, housed at the University of Cape Town,

129 simultaneously measures the sand-sized fraction along with silts and clays. Statistical moments

130 follow the Udden-Wentworth classification (Leeder, 1982) and Folk and Ward (1957)

131 classification. These data are presented in Table 1.

\section{Optically stimulated luminescence}

134 OSL dating was conducted at the Sheffield Centre for International Drylands Research

135 (SCIDR; sample codes prefixed "Shfd") and the GeoQuEST Research Centre, University of

136 Wollongong (sample codes UoW-232 to UoW-236). Both laboratories conducted field sampling,

137 equivalent dose and dose-rate measurements independently, thus providing an opportunity to test 
Final version available at http://www.sciencedirect.com/science/article/pii/S0033589409001112

138 the reproducibility of age estimates applied to sediments from the same site using a standard 139 numerical age method.

140 Samples were obtained by hammering opaque plastic tubes into fresh sediment exposures 141 or by breaking off large blocks of cemented sediment from sections. These blocks were broken 142 up under dim red/orange lighting to extract unexposed sediments. Quartz grains of $150-250 \mu \mathrm{m}$

143 (Sheffield) or 180-212 $\mu \mathrm{m}$ (Wollongong) diameters were isolated using standard procedures

144 (Bateman and Catt, 1996; Jacobs et al., 2003). All luminescence measurements were carried out

145 on Risø TL/OSL readers (Bøtter-Jensen et al., 2000) equipped with either blue LEDs ( $\Delta 470 \mathrm{~nm}$;

$14640 \mathrm{~s}$ stimulation) or a filtered (Schott GG420 + SWP interface filters) $150 \mathrm{~W}$ halogen lamp (100

147 s stimulation; samples Shfd05019 and Shfd05047 only). Resulting luminescence signals were

148 detected with EMI 9635Q photomultiplier tubes combined with Hoya U340 filters. Laboratory

149 irradiations were performed by calibrated ${ }^{90} \mathrm{Sr} /{ }^{90} \mathrm{Y}$ sources.

150 The single-aliquot regenerative-dose (SAR) protocol (Murray and Wintle, 2000) was

151 used to determine equivalent doses $\left(D_{\mathrm{e}}\right)$. Appropriate preheat temperature combinations for 152 regeneration and test doses were determined experimentally via preheat plateau tests and dose 153 recovery experiments (Murray and Wintle, 2003; table S1). Growth curves were constructed 154 using between 4 and 7 regeneration points (including a zero dose point) and were fitted using a 155 saturating exponential plus linear equation. Multi-grain $D_{e}$ values were determined from the first $1560.8 \mathrm{~s}$ of OSL, using the final $20 \mathrm{~s}$ or $8 \mathrm{~s}$ as background (for the 100-s and 40-s stimulations, 157 respectively). Tests of protocol performance were made by checking for thermal transfer, test158 dose sensitivity correction ('recycling ratio') and the presence of feldspar contamination (Duller, 159 2003). Aliquots exceeding acceptance thresholds for these tests were removed from the data sets 
Final version available at http://www.sciencedirect.com/science/article/pii/S0033589409001112

160 prior to $D_{e}$ calculation. $D_{e}$ uncertainties incorporate an instrumental reproducibility uncertainty

161 of $1 \%$, photomultiplier counting statistics and a growth curve fitting uncertainty.

162 For each sample, between 12 and 51 aliquots produced acceptable $\mathrm{D}_{\mathrm{e}}$ estimates. The

163 resulting $\mathrm{D}_{\mathrm{e}}$ distributions were 'overdispersed' by between 4 and $20 \%$ (i.e., spread in $\mathrm{D}_{\mathrm{e}}$

164 remaining after known measurement uncertainties have been taken into account; Table 2 and

165 Figure S1). Well-bleached, multi-grain aliquots composed of quartz grains may have $\mathrm{D}_{\mathrm{e}}$

166 distributions overdispersed by as much as 20\% (Jacobs et al., 2003; Galbraith et al., 2005).

167 Accordingly, we consider that the $\mathrm{D}_{\mathrm{e}}$ estimates for all aliquots of each sample record the same

168 depositional event. Thus, weighted mean $\mathrm{D}_{\mathrm{e}} \mathrm{s}$ and standard errors were calculated using the

169 'central age model' (Galbraith et al., 1999), with an additional uncertainty of $2 \%$ associated with

170 laboratory beta-source calibration included for age calculation. The final presented age is

171 accompanied by its 1-sigma uncertainty.

172 The external beta and gamma dose rates were estimated from the concentrations of

173 uranium (U), thorium (Th) and potassium (K) derived via in situ gamma spectrometry, or, where

174 this was not possible, via thick source alpha counting (TSAC; U and Th) and inductively coupled

175 plasma-mass spectrometry (ICP-MS; K; Sheffield); or a combination of TSAC and beta counting

176 (Wollongong). These values were converted to annual dose rates (Adamiec and Aitken, 1998;

177 Marsh et al., 2003), making allowance for beta-dose attenuation (Mejdahl, 1979) and sample

178 water content (Aitken, 1985). In the case of samples deposited within sub-aqueous environments,

179 the modern (measured) water contents, which were as low as $1 \%$, were considered

180 inappropriate. For these samples time-weighted water content was determined based on the

181 progressive (linear) reduction of water content during burial from a (laboratory-determined)

182 saturated content to the modern value. As an assessment of the sensitivity of sample age to water 
Final version available at http://www.sciencedirect.com/science/article/pii/S0033589409001112

183 content, it is noted that the total dose rate decreases (and optical age increases) by ca. $1 \%$ for

184 each $1 \%$ increase in water content. An absolute water content uncertainty of $\pm 5 \%$ was

185 propagated through to the final age determination (Aitken, 1985), which for most samples

186 incorporates a large proportion of the burial history variation in water content.

187 The agreement between the $\mathrm{U}$ and Th concentrations derived by TSAC or gamma

188 spectrometry, and supplementary ICP-MS measurements for samples from two sites suggest that 189 no significant U-series disequilibrium problems are present (Table S2). To calculate the optical 190 ages we assumed that the measured radionuclide activities have prevailed throughout the period

191 of burial. Cosmic dose rates were determined following Prescott and Hutton (1994) and modified

192 to account for changing overburden depth through time. This is achieved through the iterative

193 adjustment of the suite of initial (uncorrected) ages in a stratigraphic sequence (see Roberts et al., 194 2008).

195

\section{Amino acid racemization $(A A R)$}

AAR allows the determination of the relative age of fossils through the analysis of the D /

$198 \mathrm{~L}$ ratios of amino acid optical isomers. AAR provided a supplementary means of relative age

199 estimation where OSL sampling was not possible, as well as independent age verification at sites

200 where both techniques were applied. AAR analyses were conducted on marine shells (Turbo

201 spp.) and on terrestrial gastropods (Tropidophora sp.). The degree of racemization for the amino

202 acids glutamic acid and valine was determined using Reverse Phase High Performance Liquid

203 Chromatography (Kaufman and Manley, 1998). Analyses were undertaken on the total

204 hydrolysable amino acids, after hydrolysis for 22 hours at $110^{\circ} \mathrm{C}$ in $8 \mathrm{~mol} \mathrm{HCl}$. The analytical

205 procedure involved the pre-column derivatization of DL-amino acids with $o$-phthaldialdehyde 
Final version available at http://www.sciencedirect.com/science/article/pii/S0033589409001112

206 (OPA) together with the chiral thiol, $N$-isobutyryl-L-cysteine (IBLC) to yield fluorescent

207 diastereomeric derivatives of the chiral primary amino acids. Amino acid $\mathrm{D} / \mathrm{L}$ ratio

208 determinations were undertaken using an Agilent 1100 HPLC with a C-18 column. These data

209 are presented in Table 3.

210

\section{Study sites}

212 The southern Cape coastline constitutes a passive intra-plate continental margin. The

213 fragmentation of Gondwanaland initiated a narrow coastal platform seaward of the Great

214 Escarpment, which was subsequently broadened by a series of planation events throughout the

215 Cenozoic (Marker and Holmes, 2005). The region is characterized by a low-gradient continental

216 shelf, which reaches a maximum width of about $130 \mathrm{~km}$ south of Still Bay and progressively

217 narrows in an eastwards direction (Figure 1). The morphology of the modern coastline east of

218 Cape Agulhas comprises a series of resistant headlands, typically formed from Paleozoic Cape

219 Supergroup quartzites, and sweeping bays mantled by a veneer of Cenozoic marine and eolian

220 sediments.

222 Swartvlei Estuary, Sedgefield

The Sedgefield-Wilderness embayment is characterized by a series of shore-parallel

224 "cordons" thought to have formed during multiple Pleistocene sea-level high stands (Illenberger,

225 1996). Martin (1962) described a number of emergent marine deposits along the modern

226 shoreline between Gericke Point and Eilandvlei (Figure 2). These were reported to reach a

227 maximum altitude of $7.5 \mathrm{~m}$ amsl. We were unable to relocate these exposures in the field and 
Final version available at http://www.sciencedirect.com/science/article/pii/S0033589409001112

228 instead report a stratigraphic succession exposed at the mouth of the Swartvlei Estuary about 5

$229 \mathrm{~km}$ farther east.

Two sections $30 \mathrm{~m}$ apart were examined. In both sections the basal facies (from $0 \mathrm{~m}$

231 amsl) comprises $0.5-1.0 \mathrm{~m}$ (lower contact not exposed) of medium to coarse grained, well-sorted,

232 structureless calcarenite (Figure 3). The transition from this lower unit to the overlying facies is

233 notably disconformable and marked by rip-up clasts. This lower unit was apparently lithified and

234 partially reworked (forming a transgressive lag) prior to the deposition of the overlying facies

235 (Figure S2).

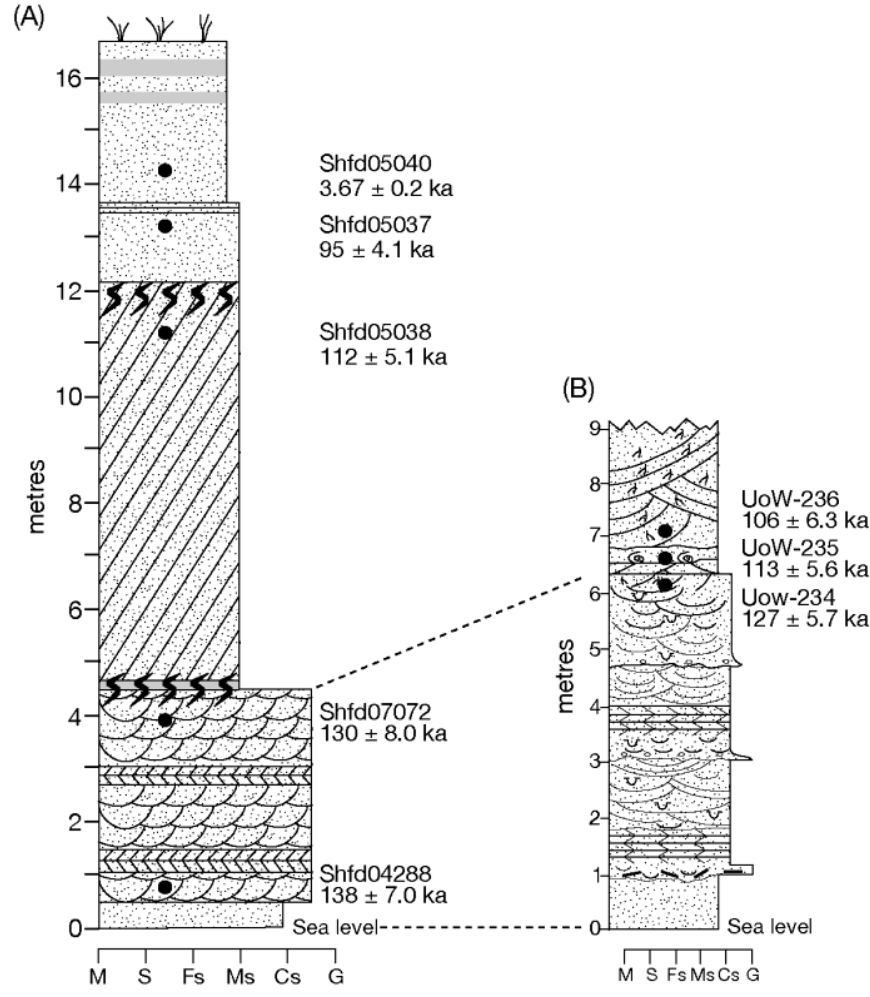

Calcarenite: Medium-grained; well sorted; large scale plana cross stratified; heavily roo bioturbated in part; lower contact comformable.

Calcarenite: Medium to coarse-grained, gravel in part (Cape Supergroup clasts) poorly to moderately well sorted; trough cross-stratified with some herringbone cross-stratification; shelly in part; bioturbated in part; erosive basal contact with calcrete interclasts.

Unconformable contact.

Calcarenite: Medium grained; well sorted; massive.

Unconsolidated dune sands
Soil
High angle planar cross bedded Eolianite
Laminated bedding
Trough cross bedding

- OSL sample
Herringbone cross stratification

S5 Biotubation

$\lambda$ Roots

बप्र Shells

.... Unconformity
Interpretation

Regressive eolian deposition

\section{Estuarine tidal inlet:} migration of sinous crested mega-ripples during ebb and flood; vertical stacking of sedimentary facies during transgression.

\section{Foreshore/Shoreface}

$M=$ Mud

$S=$ Silt

$\mathrm{Fs}=$ Fine sand

Ms $=$ Medium sand

Cs = Coarse sand

$\mathrm{G}=$ Gravel

237 Figure 3: The Swartvlei Estuary sample site. (A) Stratigraphy of primary site (B) detailed stratigraphy of the 238 estuarine inlet facies from offset section, showing OSL samples UoW-234, UoW-235 andUoW-236. 
Final version available at http://www.sciencedirect.com/science/article/pii/S0033589409001112

Overlying this from $0.5-1.0 \mathrm{~m}$ amsl up to $5.6 \mathrm{~m}$ amsl is a very coarse-grained,

240 moderately sorted, thickly bedded calcarenite, structured by trough cross-bedding and, less-

241 commonly, herringbone cross-bedding (Figure 3; Figure S3). The strata contain marine

242 mollusks, including limpets (Patella sp.) and cockles (Cardiidae) as well as vertical burrows of

243 the ichnogenera Skolithos and Ophiomorpha (e.g. Tomazelli and Dillenburg, 2007). Numerous

244 internal scours mantled by coarse, occasionally gravelly, detritus are observed. This facies

245 reaches $4.8 \mathrm{~m}$ amsl section A, but is slightly thicker (5.6 $\mathrm{m}$ amsl) in section B (Figure 3B). The

246 lithology and sedimentary structures of this facies are indicative of a tidal inlet environment and

247 suggest a setting dominated by the uni- and bidirectional migration of sub-aqueous mega-ripples,

248 giving rise to the trough and herringbone cross bedding (Reddering, 1983; Massari and Parea,

249 1988). This interpretation is analogous to the existing tidal inlet of the Swartvlei Estuary. The

250 indications of reversing currents within erosional scours are compatible with deposition in

251 migrating tidal channels (scour and fill). Generally, the contact with the overlying eolianite

252 facies at $4.5-5.6 \mathrm{~m}$ amsl appears conformable, although a coarse shelly (possibly deflationary)

253 lag is sporadically exposed. The overlying eolianite facies displays high-angle planar cross-

254 bedding typical of Pleistocene dunes in this region. Eight OSL samples, encompassing three

255 samples from the inlet facies and five samples from the eolianite were obtained from this site.

257 Groot Brak Estuary

$25865 \mathrm{~km}$ west of Sedgefield, calcified shallow marine and eolian sediments are exposed on

259 the banks of the Groot Brak Estuary (Figures 1 and 4). This succession is exposed/partially

260 exposed up to $450 \mathrm{~m}$ inland of the estuary mouth, whereupon it becomes inaccessible for study

261 due to the terrain and vegetation. The succession comprises a lower facies (0-1.0 m amsl) of 
Final version available at http://www.sciencedirect.com/science/article/pii/S0033589409001112

262 medium grained, massive calcarenite, overlain by moderately-sorted, coarse-grained, shelly 263 calcarenites, grading to gravel in places (1.0 - $4.9 \mathrm{~m}$ amsl). Trough cross-stratification is the 264 dominant sedimentary structure in the latter facies, along with occasional herringbone cross265 stratification. This bears close similarities with the exposure at the Swartvlei Estuary and is 266 interpreted similarly.

267 This facies is conformably overlain by well sorted, gently seaward and landward dipping 268 low-angle cross-stratified calcarenites, which reach up to $9.8 \mathrm{~m}$ amsl. This low-angle cross269 stratified facies is interpreted as a beach berm swash deposit (Reddering, 1983; Short, 1984), 270 modern analogues of which form on the banks of the contemporary estuary. Today these are 271 usually the product of storms or spring high tides and are observed to reach up to $2 \mathrm{~m}$ above the 272 tidal channel. This beach berm facies is conformably overlain by high-angle cross-stratified 273 eolianites. OSL samples were obtained from the base of the beach berm facies $(9.0 \mathrm{~m}$ amsl) and 274 from the base of the overlying eolianite (10.5 m amsl). 


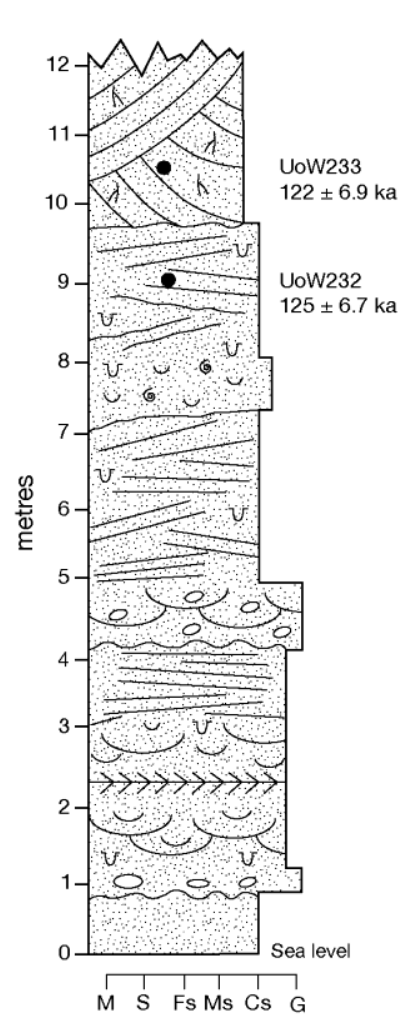

\section{Description}

Calcarenite: Medium-grained, well sorted; large-scale planar cross-stratified; heavily root bioturbated in part; lower contact comformable.

Calcarenite: Medium to coarse-grained, pebbly in part; moderately to well sorted; low angle cross-stratified with some low angle discordances; shelly in part; slightly erosive but essentially conformable basa contact.

Calcarenite: Medium to coarse-grained; gravelly in part (Cape Supergroup clasts); poorly to moderately well sorted; trough cross-stratified with some herringbone cross-stratification; shelly in part; bioturbated in part; erosive basal contact with calcrete interclasts; unconformable contact.

Calcarenite: Medium grained; well sorted; massive.

\section{Interpretation}

Regressive eolian deposition

\section{Beach berm:}

Wave swash lamination during storms and spring

high tides; some eolian

influence also likely.
Stacked Tidal inlets:

Migration of sinuous crested megaripples during ebb and

flood; vertical stacking of

sedimentary facies; erosion

of older calcified tidal inlet

deposits.

Beach sanc:

Massive, possibly heavily

\begin{tabular}{|llll|}
\hline Unconsolidated dune sands & $\mathrm{Ah}$ Roots & $\mathrm{M}=$ Mud & $\mathrm{Ms}=$ Medium sand \\
\hline Low angle cross-stratification & $\mathrm{GU}$ Shells & $\mathrm{S}=$ Silt & $\mathrm{Cs}=$ Coarse sand \\
Trough cross bedding & - OSL sample & $\mathrm{Fs}=$ Fine sand & $\mathrm{G}=$ Gravel \\
Herringbone cross stratification & & & \\
\hline
\end{tabular}

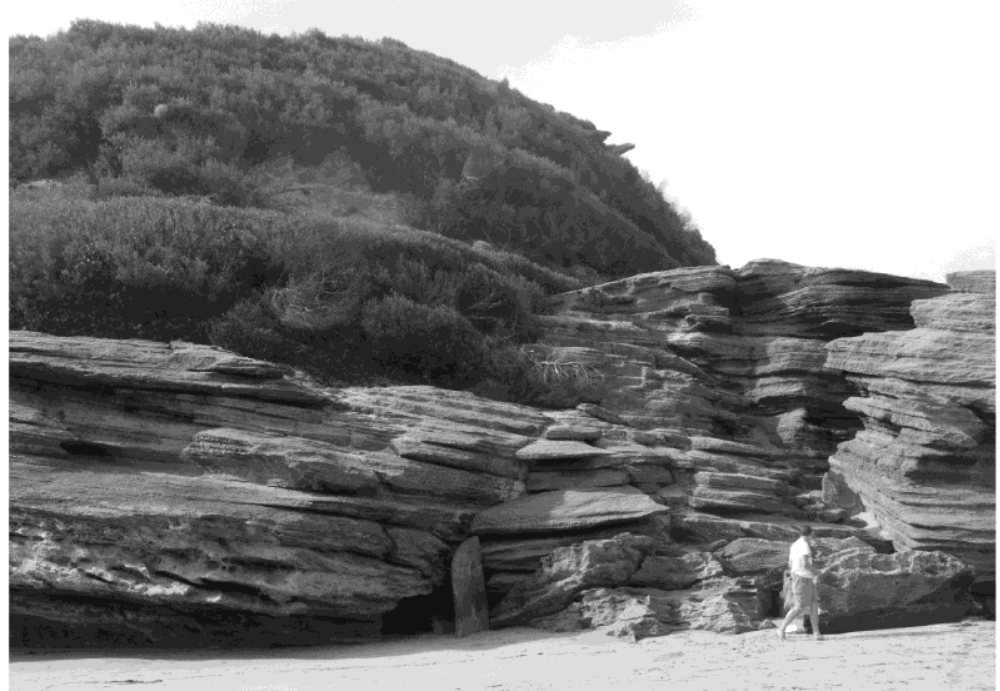

277 Figure 4: Upper: the stratigraphic log for the Groot Brak Estuary site with OSL samples marked. See figure 3 legend

278 for log symbols. Lower: view of the sample site showing the low angle cross stratified beach berm facies. 
Final version available at http://www.sciencedirect.com/science/article/pii/S0033589409001112

\section{Cape Agulhas}

Two sites in the Cape Agulhas area display evidence pertinent to palaeosea-level

fluctuations (Figure 5). Northeast of Cape Agulhas, a raised beach deposit with a basal altitude of $3.0 \mathrm{~m}$ amsl is exposed landward of the modern rocky shoreline. The lower part of the section (Figure 6) comprises a ca. 0.8-m-thick unit (basal contact not exposed) composed of tightlypacked and well-rounded clasts of quartzite (long axis 0.1-0.5 m) and includes the marine mollusks Turbo sp. and Patella sp. The faunal remains and lithology are indicative of a rocky shoreline comparable to the present setting. This gravel beach facies is unconformably overlain by a $3.9 \mathrm{~m}$ thick deposit of structureless sands composed mostly of comminuted shell (ca. $84 \%$ carbonate by mass). The lithology and grain size parameters of these sands (mean 1.1ø; sorting 0.36; skewness 0.11), contrast sharply with nearby eolianites (Table 1) and the former are interpreted as a wave winnowed foreshore deposit. These calcareous sands grade upwards into a pedogenic calcrete, capped by a well-developed laminated hardpan at $7.6 \mathrm{~m}$ amsl, which is in turn overlain by a modern soil. An OSL sample was obtained from these foreshore sands at 5.6 m amsl.

Further sampling was carried out in the eroding backshore cliffs at Hoë Walle, west of Cape Agulhas (Malan, 1990; Bateman et al., 2004; Figure 5). The lower part of the section (0 $4.5 \mathrm{~m}$ amsl) comprises structureless, uncemented calcareous sands within which three paleosols of variable maturity are preserved. The most mature paleosol (paleosol 2; Figure 7) lies at $4.5 \mathrm{~m}$ amsl, and predates $88 \pm 4$ ka (Shfd02131; Bateman et al., 2004). In this study an additional OSL sample was obtained from a structureless sandy unit at $4 \mathrm{~m}$ amsl, $0.5 \mathrm{~m}$ below paleosol 2 . In addition, a specimen of the terrestrial gastropod Trophidophera $s p$. was obtained from the underlying paleosol 3 at $3.4 \mathrm{~m}$ amsl. 


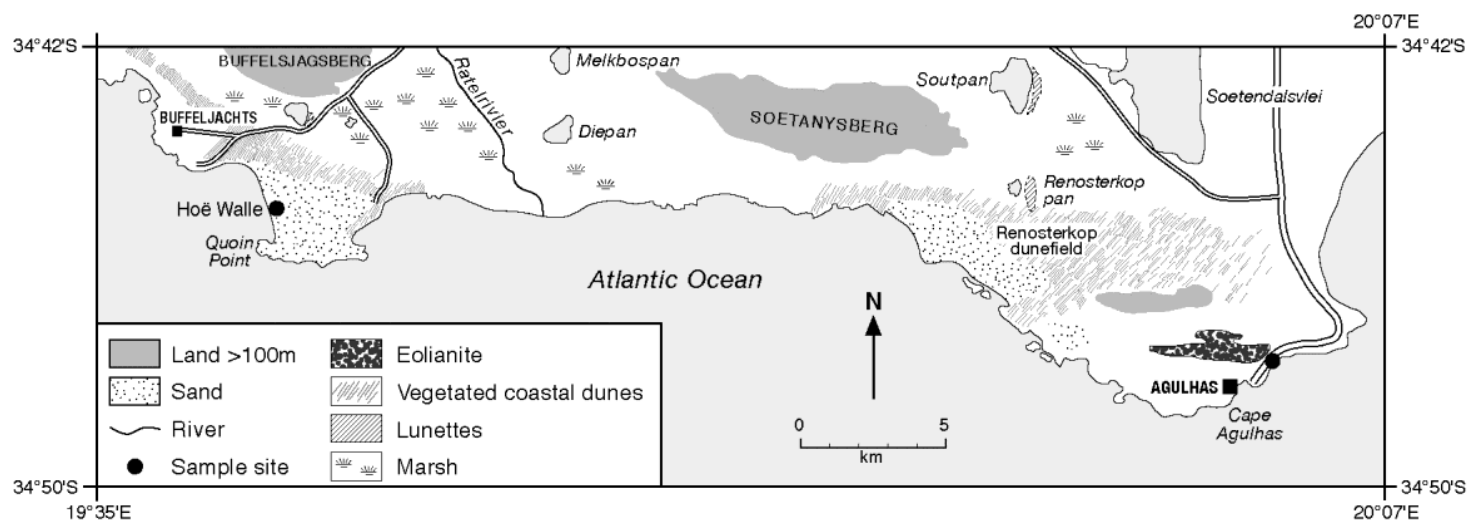

305 Figure 5: Sampling locations in the Cape Agulhas area

Geochronological Results

Swartvlei Estuary

Eight OSL samples were obtained from the Swartvlei Eustary (Figure 3 and Table 2).

310 Three were collected from the tidal inlet facies (UoW-234, Shfd07072 and Shfd04288), and five

311 from the overlying eolian facies (samples Shfd05038-05040, UoW-235 and UoW-236). Sample

312 Shfd04288 (138 $\pm 7 \mathrm{ka})$ provides a basal age for the tidal inlet facies $(1 \mathrm{~m} \mathrm{amsl})$. The distinct

313 lithofacies sequence at the site enabled easy correlation between the two measured sections, with

314 UoW-234 and Shfd07072 both corresponding with the top of the tidal inlet facies (127 $\pm 6 \mathrm{ka}$

315 and $130 \pm 8$ ka respectively). The eolianite immediately overlying the inlet facies produced OSL

316 ages of $113 \pm 6 \mathrm{ka}(\mathrm{UoW}-235)$ and $106 \pm 6 \mathrm{ka}$ (UoW-236). Remaining ages from the eolianite

317 were $112 \pm 5 \mathrm{ka}$, (Shfd05038) and $95 \pm 4 \mathrm{ka}(\operatorname{Shfd05039);~with~the~overlying~Holocene~dune~}$

318 sands dating to $3.67 \pm 0.2 \mathrm{ka}$ (Shfd05040). The stratigraphic concordance of the eight ages

319 derived from this site, which were sampled and measured independently at Sheffield and

320 Wollongong, provides additional confidence in this chronology. 
Final version available at http://www.sciencedirect.com/science/article/pii/S0033589409001112

334 degree of racemization of valine ranged from 0.35 (UWGA5232A-F) to 0.41 (UWGA5233A-C),

335 with glutamic acid showing slightly higher D/L values of 0.41 (UWGA5232A-F) and 0.46

336 (UWGA5233A-C). An operculum from a further specimen of Turbo sp. yielded a minimum 337 radiocarbon age of $>36,244{ }^{14} \mathrm{C}$ yr BP (Wk-19265).

\section{Groot Brak Estuary}

OSL ages of $125 \pm 7 \mathrm{ka}$ (UoW-232) and $122 \pm 7 \mathrm{ka}$ (UoW-233) were obtained for the samples from the beach berm and eolianite facies respectively (Table 2; Figure 4). Like the Swartvlei Estuary site, these ages are stratigraphically concordant and the facies relations at the two sites are comparable; the similarity in ages provides further confidence in these data.

\section{Cape Agulhas}

The sample from the coarse sand deposits at $5.6 \mathrm{~m}$ amsl (Shfd05019; Figure 6) produced an OSL age of $118 \pm 7.2 \mathrm{ka}$ (Table 2). This sample has the highest $\mathrm{D}_{\mathrm{e}}$ overdispersion in our data set (20\%; Figure S1). This over-dispersion is not excessive (Jacobs et al., 2003), and the equivalent dose distribution, although relatively broad, is not strongly skewed. Two specimens of Turbo sp. were sampled from the raised gravel beach facies for AAR analysis (Table 3). The 
Final version available at http://www.sciencedirect.com/science/article/pii/S0033589409001112

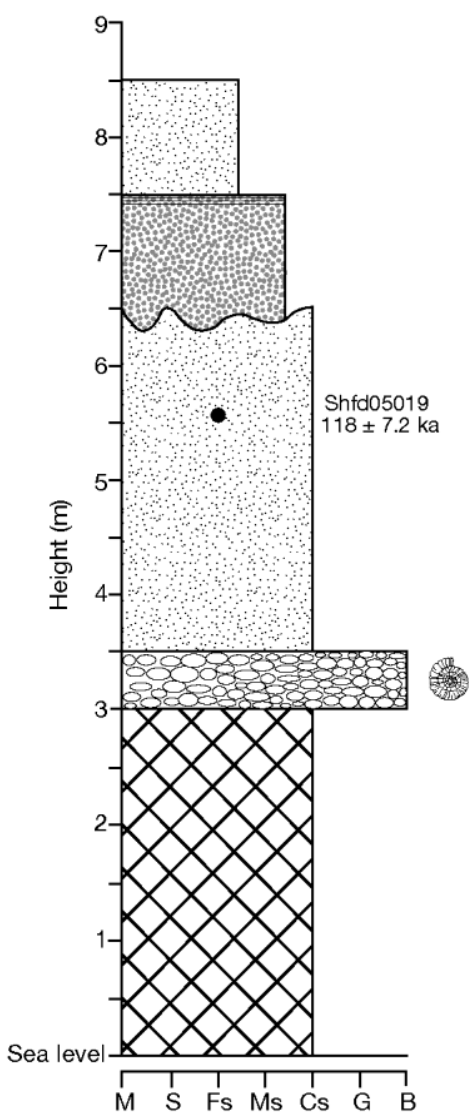

\section{Description}

Sands: Medium-grained organic rich, clasts of calcrete found at base of unit.

Calcrete: Massive weakly cemented. Increasingly indurated to top of unit. Sands: Structureless calcareous coarse
sands (median 1.1 phi) composed mostly of communited shell 2.5 Y $8 / 3$.

\section{Interpretation}

Modern soil.

Pedogenic calcrete formed by alteration of beach sands facies.

Beach-face deposit.

Winnowing of fine sands partial or complete fragmentation of nearby rock-dwelling molluscs.

Conglomerate: Clast supported, comprising well rounded quartzite clasts. Tightly packed with sandy matrix.

Gravel beach deposit associated with rocky coastline.

\begin{tabular}{|l|l|}
\hline$M=$ Mud \\
Unexposed & S Silt \\
$\mathrm{Fs}=$ Fine sand \\
$\mathrm{Ms}=$ Medium sand \\
$\mathrm{Cs}=$ Coarse sand \\
$\mathrm{G}=$ Gravel \\
$\mathrm{B}=$ Boulders \\
\hline
\end{tabular}

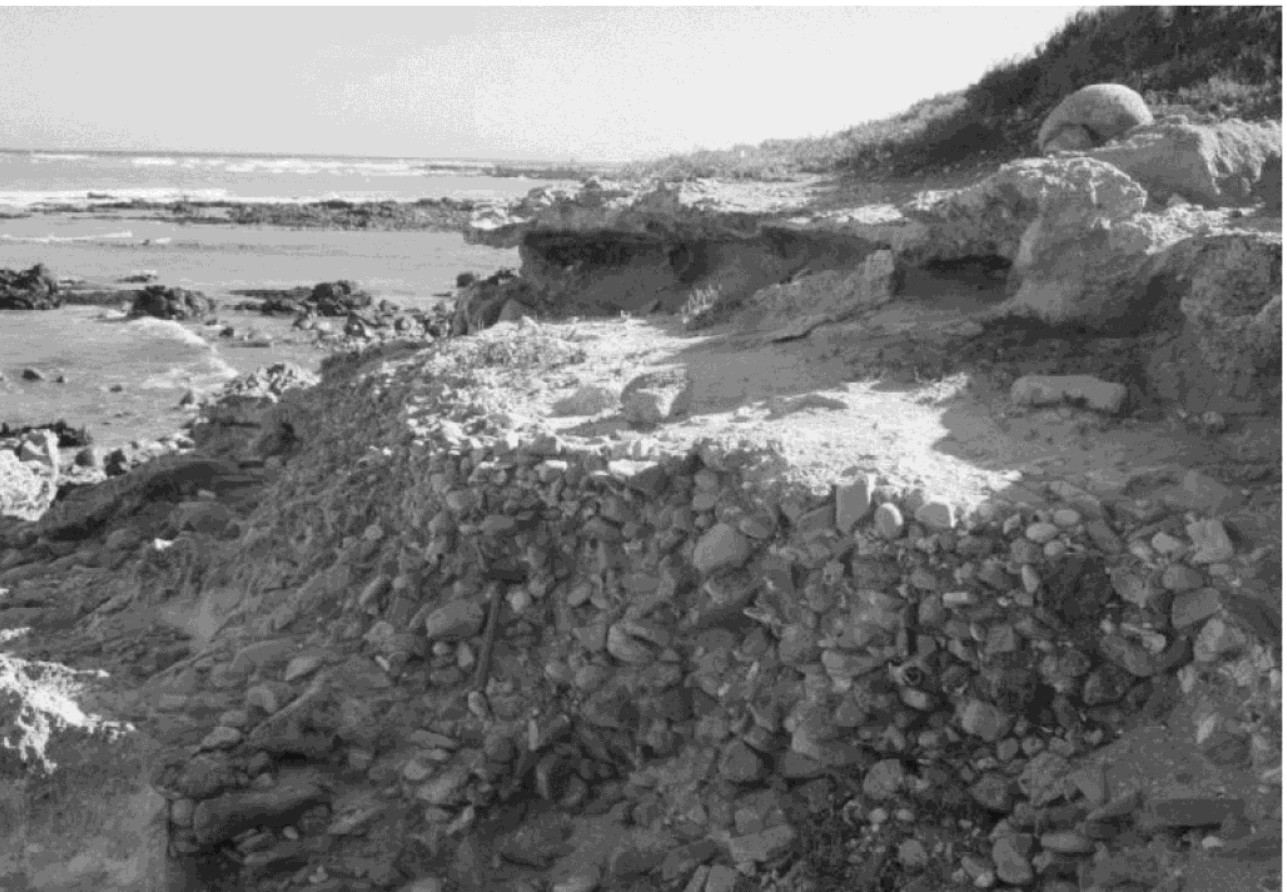

340 Figure 6: The stratigraphic section for the raised beach at Cape Agulhas. A photograph of the raised gravel beach

341 deposit is also shown below. Geological hammer center-left for scale. 
Final version available at http://www.sciencedirect.com/science/article/pii/S0033589409001112

At Hoë Walle an OSL age of $104 \pm 7 \mathrm{ka}(\operatorname{Shfd05047)}$ was obtained for the sample $0.5 \mathrm{~m}$

343 below paleosol $2(4.5 \mathrm{~m}$ amsl). This is stratigraphically consistent with published OSL ages from

344 this site (Bateman et al., 2004; Figure 7) and brackets the formation of paleosol 2 to $<104 \pm 7$

$345 \mathrm{ka}$ and $>88 \pm 4 \mathrm{ka}$. AAR data for the terrestrial gastropod sampled from paleosol 3 (3.4 m amsl)

346 reveal a lower degree of racemization ( $\mathrm{D} / \mathrm{L}$ ratios of $0.274 \pm 0.019$ and $0.373 \pm 0.022$ for valine

347 and glutamic acid respectively; Table 3) than MIS 5e gastropods elsewhere on this coastline

348 (Roberts et al. 2008; valine 0.379 \pm 0.103; glutamic acid 0.576 \pm 0.075 ; UWGA5225A-C),

349 lending further support to the OSL ages and the inference that that this sequence post dates the

350 last interglacial (MIS 5e; 130-116 ka).

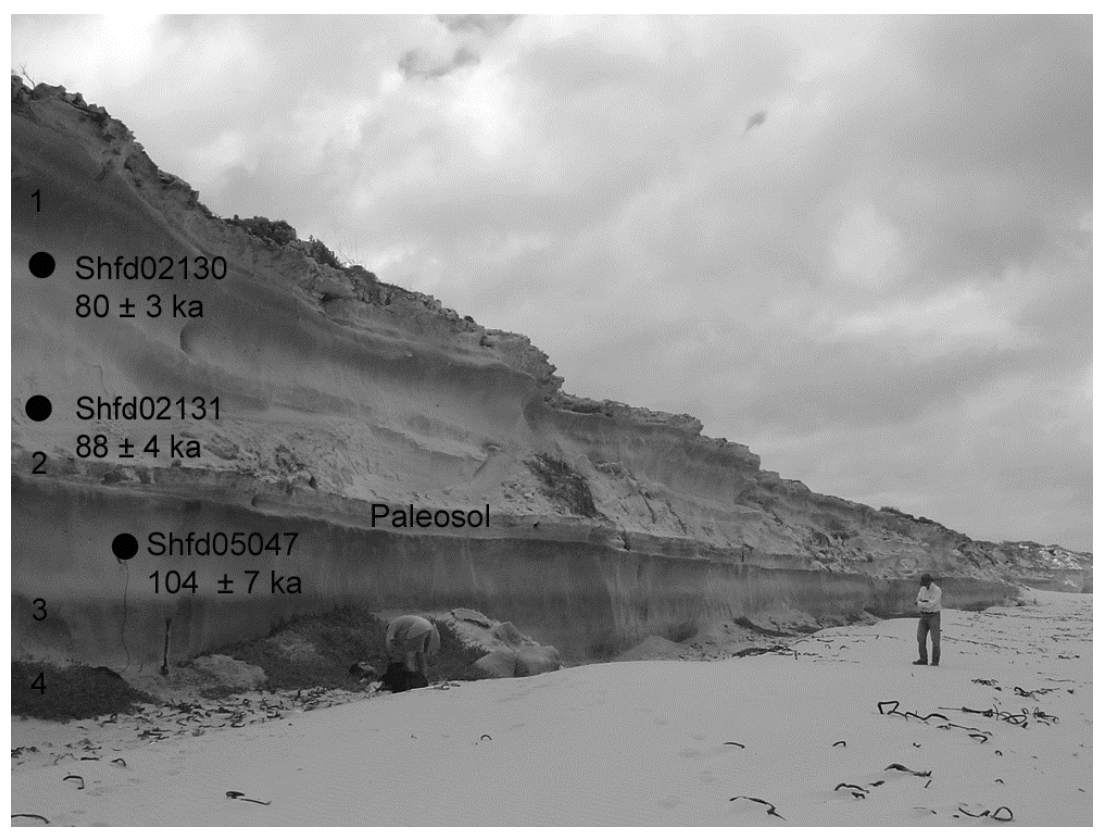

353 Figure 7: The sample site at Hoë Walle. Sample locations and ages reported in Bateman et al (2004) are marked, as

354 is the current sample. Four paleosols identified at this site are numbered. The most prominent paleosol (2) comprises 355 indurated planar laminated silty sands. Diffuse paleosols (3 and 4) are marked by slight organic matter enrichment 356 and loss of bedding structure. A specimen of the dune snail Trophidophera sp. was sampled from paleosol 3. 
Final version available at http://www.sciencedirect.com/science/article/pii/S0033589409001112

358

359

360

361

362

363

364

365

366

367

368

369

370

371

372 this index point is complicated by the overall seaward dip of the exposed strata. The maximum

373 landwards extent of the inlet/eolian facies change is not exposed and the index point of $5.6 \mathrm{~m}$

374 amsl must be treated as a minimum palaeosea-level estimate. Given that the angle of dip is low

$375\left(1-2^{\circ}\right)$ the index point is unlikely to rise much higher, which we estimate to be no more than ca. 1

376 m. (i.e., $6.6 \mathrm{~m}$ amsl). The indicative meaning of this index point must also account for the water

377 depths in which the characteristic tidal inlet facies form. Reddering (1983) provides a detailed

378 overview of a wave-dominated micro-tidal inlet at Plettenberg Bay (Figure 1). Here, trough

379 cross-bedded flood tide inlet facies, comparable to those at Swartvlei are currently deposited 0.5

$380-3.5 \mathrm{~m}$ below the mean water level. Given similar water depths in the contemporary inlet at 
Final version available at http://www.sciencedirect.com/science/article/pii/S0033589409001112

381 Swartvlei we infer an indicative meaning of ca. $8.5 \mathrm{~m}$ amsl for this index point, which accounts

382 for both the dip of the strata and the probable depositional environment of the inlet facies. The

383 presence of the inchnogenera Ophiomorpha and Skolithos throughout the inlet facies, which have

384 been associated with sediments close to the average low tide level and water depths less than 5

385 m, supports this interpretation (Frey et al., 1978; Tomazelli and Dillenburg, 2007).

386 Notwithstanding, estuaries/inlets along the southern Cape coastline are characterized by

387 considerable morphological dynamism (Reddering, 1983; Cooper, 2001) and so an associated

388 indicative range of $\pm 2 \mathrm{~m}$ is applied (Table 4).

389 At Groot Brak Estuary the tidal inlet facies reaches an altitude of $4.9 \mathrm{~m}$ amsl. However,

390 like Swartvlei these exhibit a very low seawards dip $\left(<1^{\circ}\right)$, which can be projected inland to ca.

$3917.3 \mathrm{~m}$ amsl. The OSL sample (125 $\pm 7 \mathrm{ka}$; UoW-232) obtained from beach berm facies at $9 \mathrm{~m}$

392 amsl provides an index point marking a regressive sea-level trend (transition from beach berm to

393 eolian facies). It also provides a minimum age for the inlet facies. The contact between the inlet

394 facies and beach berm facies is conformable, and this OSL age is likely to broadly reflect the age

395 of the former. Modern analogues for the beach berm facies are deposited up to $2 \mathrm{~m}$ amsl,

396 implying an indicative meaning of ca. $7.0 \mathrm{~m}$ amsl for the index point. However, swash-formed

397 deposits are associated with relative wide indicative ranges (Reddering, 1983; Ferranti et al.,

398 2006), which we estimate as $\pm 3 \mathrm{~m}$. Given a maximum exposed altitude of $9.8 \mathrm{~m}$ amsl, a

399 maximum paleosea level in the region of $7.8 \mathrm{~m}$ amsl is inferred for the beach berm facies. This is

400 consistent with the maximum sea level inferred from the inlet facies and with interpretations at

401 Swartvlei.

402

At Cape Agulhas the foreshore deposit dated by OSL provides a sea-level index point at

$4035.6 \pm 3 \mathrm{~m}$ amsl (118 $\pm 7 \mathrm{ka}$; Shfd05019). This is associated with a relatively large indicative 
Final version available at http://www.sciencedirect.com/science/article/pii/S0033589409001112

404 range (Table 4), which reflects the unknown affects of degradation during the very evident

405 pedogenesis at this site, possible damage from road construction above the sample site, and more

406 fundamentally the wide indicative range inherently associated with sandy foreshore deposits

407 (Short, 1984; Ferranti et al., 2006). The site stratigraphy implies, with the noted caveats, that sea

408 level may have reached as high as ca. $7.5 \mathrm{~m}$ amsl (Figure 6). Constraining the absolute age of

409 the gravel beach facies is difficult as there are few age-calibrated AAR data for southern African

410 Turbo specimens. The Cape Agulhas specimens display a significantly higher degree of

411 racemization than a mid-Holocene Turbo cidaris specimen from the same area $(0.187 \pm 0.018$;

412 Table 3; Bateman et al., 2008).

413 A survey of the degree of racemization in a wide range of molluscan fossil genera of late

414 Pleistocene age from southern Australia (although not including Turbo) suggests that the Cape

415 Agulhas Turbo sp. shells are significantly older than the minimum radiocarbon age, assuming

416 that comparable modern mean annual temperatures imply, as corollary, comparable diagenetic

417 temperatures (Murray-Wallace, 2000). The depositional setting and the degree of racemization of

418 glutamic acid and valine in the Turbo specimen support the assumption that the Turbo sp. shells

419 are broadly contemporaneous with the overlying sands (118 $\pm 7 \mathrm{ka})$, and that the true age of the

420 Turbo sp. specimens is significantly greater than the minimum radiocarbon age.

421 Overall, the geomorphic evidence at Cape Agulhas also implies two distinct sea-level

422 phases; initially a gravel beach at 3.0-3.8 $\mathrm{m}$ amsl, with a subsequent sandy foreshore deposit

423 reaching ca. $7.5 \mathrm{~m}$ amsl. This distinct shift in depositional environment probably reflects an

424 adjustment in wave energies around the headland as the shoreline reconfigured.

425 The OSL ages from Hoë Walle provide sea-level limiting points (i.e., maximum possible

426 sea levels), as sea level must have been lower than the sampled altitude to allow eolian sand 
Final version available at http://www.sciencedirect.com/science/article/pii/S0033589409001112

427 transport and subsequent soil (paleosol) development. Thus, the OSL ages at this site suggest

428 landscape stability (soil formation) and sea levels probably lower than $4 \mathrm{~m}$ amsl throughout the

429 period ca. 111-77 ka (maximum and minimum ages, incorporating 1 sigma uncertainties for the

430 OSL samples bracketing paleosol 2).

431 The generally conformable interface between the inlet/beach berm and eolianite facies at

432 Swartvlei and Groot Brak implies a limited pause in sedimentation (only a minor deflationary lag

433 is evident at Swartvlei) before the initiation of eolian activity, determined via OSL to have

434 occurred during the period $122 \pm 7 \mathrm{ka}$ (UoW-233) to $113 \pm 6 \mathrm{ka}$ (UoW-235). However, it is

435 difficult to ascertain the extent to which the sampled regressional sequences also record coastal

436 progradation due to increased sediment supply. In the case of the Wilderness and Still Bay

437 regions, the formation of extensive barriers (“cordons") throughout MIS 5 (ca. 130-70 ka)

438 reflects the delivery of large volumes of sediment to the region's beaches. The spread of eolianite

439 OSL ages in this study is consistent with the regional record of eolian activity along this

440 coastline, which indicates that dune accumulation remained high throughout and subsequent to

441 MIS 5e before diminishing towards the MIS 5a/4 transition (Carr et al., 2007; Roberts et al.,

442 2008; Roberts et al 2009). In contrast with evidence elsewhere in the Wilderness dune cordons

443 (Carr et al., 2007), the Swartvlei Estuary site does not record eolian deposition at the height of

444 MIS 5e, probably reflecting the flooding of this sector of the Wilderness Embayment.

446 Wider significance

447 With consideration of the age uncertainties, all of the marginal marine / inlet facies

448 provide ages consistent with MIS 5e and reveal that sea levels comparable to or above present

449 were attained between $138 \pm 7 \mathrm{ka}(\operatorname{Shfd04288)})$ and $118 \pm 7 \mathrm{ka}(\operatorname{Shfd05019)}$. These broadly 
Final version available at http://www.sciencedirect.com/science/article/pii/S0033589409001112

450 accord with expected timing of MIS 5e from the benthic oxygen isotope record (130-117 ka; e.g.

451 Martinson et al., 1987; Lisiecki and Raymo, 2005), as well as Waelbroeck et al.'s (2008) recent

452 estimate for the onset of the MIS 5e high stand (126 $\pm 1.7 \mathrm{ka})$ based on coral reef data from a

453 range of near and far-field locations (Bahamas, Hawaii and Western Australia). The evidence of

454 two phases of higher sea level at Cape Agulhas also accords with the recent arguments of Hearty

455 et al. (2007). The OSL ages from the near the top of the Agulhas site (118 $\pm 7 \mathrm{ka})$, the

456 lowermost eolianite at the Swartvlei Estuary (113 $\pm 6 \mathrm{ka})$, and the Groot Brak eolianite (122 \pm 7

$457 \mathrm{ka}$ ) are broadly consistent (given uncertainties) with the expected timing of the MIS 5e/5d sea-

458 level regression ca. 118 - 115 ka (Stirling et al. 1998; Speed and Cheng 2004; Hearty et al.,

459 2007), as well as the marine oxygen isotope record (Martinson et al., 1987). In contrast to the

460 interpretation of Ramsay and Cooper (2002), none of the southern Cape inlet or shoreface facies

461 produced an age equivalent to MIS 5c (beginning ca. 106 ka; Kukla, 2000). Ramsay and

462 Cooper's (2002) interpretation was based on U-series ages of $104.9 \pm 9 \mathrm{ka}$ (Pta-U568) and $95.7 \pm$

$4634.2 \mathrm{ka}$ (Pta-U565) from oyster specimens. At present, such an interpretation is not supported by

464 coral reef evidence (e.g., Cutler et al., 2003; MIS 5c sea levels between $-14 \pm 3 \mathrm{~m}$ and $-10 \pm 3 \mathrm{~m}$ )

465 or the marine oxygen isotope stratigraphy (Martinson et a1., 1987; Waelbroeck et al., 2002;

466 Figure 8).

$467 \quad$ Figure 8 summarizes the new sea-level data from the southern Cape and the timing of 468 associated eolian activity. Overall, our data confirm sea levels significantly higher than the 469 present along the southern Cape coastline during MIS 5e, and a 6-8.5 m amsl maximum high

470 stand is inferred (Table 4). This is comparable with (undated) 5-7 $\mathrm{m}$ amsl shoreline deposits near

471 Durban (Cooper and Flores, 1991), as well as repeated reports of marine benches and terraces

472 between 5 and $8 \mathrm{~m}$ amsl elsewhere on the South African coastline (e.g., Maud, 1968; Tankard, 
Final version available at http://www.sciencedirect.com/science/article/pii/S0033589409001112

473 1976; Marker 1987). In general, these data are also consistent with MIS 5e eustatic sea-level

474 estimates from a range of Southern Hemisphere passive margin locations, including southern

475 Brazil (7 m amsl; Tomazelli and Dillenburg, 2007) and Western Australia (4-10 m amsl, with

476 two distinct terraces/sea levels inferred by Hearty et al. 2007 and O'Leary et al., 2008; [see also

477 Stirling et al., 1995, 1998]). They are also comparable to data reported for Florida (5-8 m amsl;

478 Muhs et al., 2004). They are generally higher than estimates from southern Australia (2-6 m 479 amsl; Murray-Wallace, 2002), particularly the Eyre Peninsula (ca. 2 m amsl; Murray-Wallace 480 and Belperio, 1991).

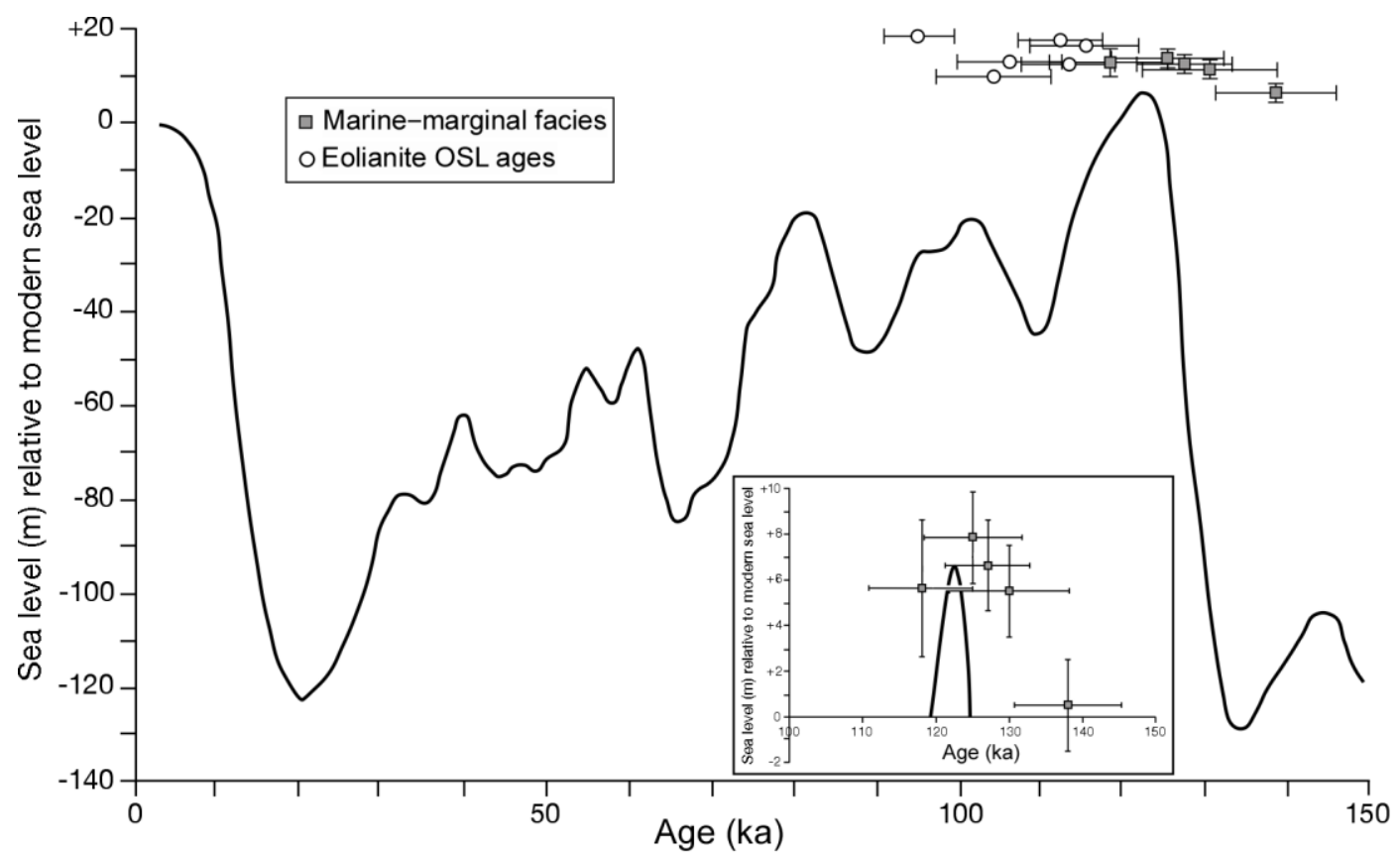

482 Figure 8: The timing of eolianite and marine-marginal sedimentation on the southern Cape coastline in relation to

483 the sea-level curve of Waelbroeck et al. (2002). Inset: indicative meanings and ranges for the marine-marginal facies 484 sampled at Swartvlei Estuary, Groot Brak Estuary and Cape Agulhas.

If assumed to primarily reflect eustatic sea-level change, a highstand of ca. 6-8.5 m amsl would support the hypothesis that melting of the Greenland ice sheet alone could not have 488 accounted for the MIS 5e sea-level high stand (e.g., Overpeck et al., 2006; Hearty et al., 2007). 
Final version available at http://www.sciencedirect.com/science/article/pii/S0033589409001112

\section{Conclusions}

This paper provides evidence for sea-level fluctuations on the south coast of South Africa during the last $140 \mathrm{ka}$ and suggests a 6-8.5 $\mathrm{m}$ amsl sea-level high stand concordant in timing with Marine Isotope Stage 5e. The sample sites at the Swartvlei and Groot Brak Estuaries reveal essentially regressive sequences, with tidal inlet facies presently exposed up to $5.6 \mathrm{~m}$ amsl. OSL ages from the overlying eolianite imply a significant sea-level regression and/or coastline progradation ca. $122 \pm 7 \mathrm{ka}-113 \pm 6 \mathrm{ka}$. At Cape Agulhas, evidence for two phases of high sea level is preserved, recording a shift from a rocky shoreline comparable to the present, to a sandy shoreline up to $7.5 \mathrm{~m}$ amsl. An OSL age of $118 \pm 7 \mathrm{ka}$ was been obtained for this final phase.

511 Africa broadly mirror eustatic sea-level changes in far-field / Southern Hemisphere sites. 
Final version available at http://www.sciencedirect.com/science/article/pii/S0033589409001112

512 However, the absolute magnitude of the high stand is greater than that recorded in some

513 locations and at present isolating the impact of hydro-isostatic effects is difficult.

Acknowledgements

This research was partially funded by the Leverhulme Trust (F/00 118/AF). South

517 African National Parks are thanked for granting permission to work in the Wilderness National

518 Park. Transport and accommodation were funded by the University of the Free State. Paul Coles

519 and Gail Holmes are thanked for cartographic assistance and sedimentological analyses

520 respectively. The South African power utility Eskom is acknowledged for permission to publish

521 confidential data. Claire Waelbroeck is thanked for providing the sea-level data used in figure 8.

522 This paper benefited from the constructive comments of Dan Muhs, John Compton and an 523 anonymous reviewer.

\section{References}

526 Adamiec G., Aitken M.J. 1998. Dose-rate conversion factors: update. Ancient TL 16, 37-50

527 Aitken, M. J. 1985. Thermoluminescence Dating. Academic Press, London.

528 Bassett, S.E., Milne, G.A., Mitrovica, J.X., Clark, P.U. 2005. Ice Sheet and solid Earth 529 influences on Far-Field sea-level histories. Science 309, 925-928.

530 Bateman, M.D., Catt, J.A. 1996. An absolute chronology for the raised beach deposits at 531 Sewerby, East Yorkshire, U.K. Journal of Quaternary Science 11, 38-395.

532 Bateman, M.D., Holmes, P.J., Carr, A.S., Horton, B.P., Jaiswal, M.K. 2004. Aeolianite and 533 barrier dune construction spanning the last two glacial-interglacial cycles from the 534 southern Cape coast, South Africa. Quaternary Science Reviews 23, 1681-1698. 
Final version available at http://www.sciencedirect.com/science/article/pii/S0033589409001112

535 Bateman, M.D., Carr, A.S., Murray-Wallace, C.V., Holmes, P.J., Roberts, D.L. 2008. A dating 536 inter-comparison study on Late Stone Age Midden deposits, South Africa.

$537 \quad$ Geoarchaeology 23, 715-741

538 Bard, E., Hamelin, B., Fairbanks, R.G., 1990, U-Th ages obtained by mass spectrometry in 539 corals from Barbados: Sea-level during the past 130,000 years. Nature 346, 456-458.

540 Baxter, A.J., Meadows, M.E. 1999 Evidence for Holocene sea-level change at Verlorenvlei, 541 Western Cape, South Africa. Quaternary International 56, 65-79

542 Bøtter-Jensen, L., Bulur, E., Duller, G.A.T., Murray, A.S., 2000. Advances in luminescence 543 instrument systems. Radiation Measurements 32, 523-528.

544 Butzer, K.W. 2004. Coastal eolian sands, paleosols, and Pleistocene geoarchaeology of the 545 Southwestern Cape, South Africa. Journal of Archaeological Science 31, 1743-1781

546 Carr, A.S., Bateman, M.D., Holmes, P.J. 2007. Developing a 150 ka luminescence chronology 547 for the coastal dunes of the southern Cape, South Africa. Quaternary Geochronology 2, $548 \quad 110-116$

549 Compton, J.S. 2001. Holocene sea-level fluctuations inferred from the evolution of depositional 550 environments of the southern Langebaan Lagoon salt marsh, South Africa. The Holocene $11,395-405$

552 Compton, J.S. 2006 The mid-Holocene sea-level highstand at Bogenfels Pan on the southwest 553 coast of Namibia. Quaternary Research 66, 303-310

554 Cooper, J.A.G. 2001. Geomorphological variability among microtidal estuaries from the wave555 dominated South African coast. Geomorphology 40, 99-122. 
Final version available at http://www.sciencedirect.com/science/article/pii/S0033589409001112

Cooper, J.A.G., Flores, R.M. 1991. Shoreline deposits and diagenesis resulting from two Late Pleistocene highstands near +5 and +6 metres, Durban, South Africa. Marine Geology 97, 325-343.

Cutler, K.B. Edwards, R.L. Taylor, F.W. Cheng, H. Adkins, J. Gallup, C.D. Cutler, P.M. Burr G.S. Bloom A.L. 2003. Rapid sea-level fall and deep-ocean temperature change since the last interglacial period. Earth and Planetary Science Letters 206, 253-271

Duller, G.A.T., 2003. Distinguishing quartz and feldspar in single grain luminescence measurements. Radiation Measurements, 37, 161-165.

Ferranti, L., Antonioli, F., Mauz, B., Amorosi, A., Dai Pra G., Mastronuzzi, G., Monaco, C., Orrù, P., Pappalardo, M., Radtke, U., Renda, P., Romano, P., Sansò, P. and Verrubbi, V. 2006. Markers of the last interglacial sea-level highstand along the coast of Italy: tectonic implications. Quaternary International 145-146, 30-54

Fleming, K., Johnston, P., Zwartz, D., Yokoyama, Y., Lambeck, K., Chappell, J. 1998. Refining the eustatic sea-level curve since the Last Glacial Maximum using far- and intermediatefield sites. Earth and Planetary Science Letters 163, 327-342

Folk, R.L., Ward, W.C., 1957. Brazos River Bar, a study in the significance of grain size parameters. Journal of Sedimentary Petrology 27, 3-26.

Frey, R.W., Howard, J.D., Pryor, W.A. 1978. Ophiomorpha - its morphologic, taxonomic, and environmental significance, Paleogeography Palaeoclimatology Palaeoecology 23, 199229

Galbraith, R. F., Roberts, R.G., Laslett, G.M., Yoshida H., Olley, J.M. 1999. Optical dating of single and multiple grains of quartz from Jinmium rock shelter, northern Australia, part 1, Experimental design and statistical models. Archaeometry 41, 339-364. 
Final version available at http://www.sciencedirect.com/science/article/pii/S0033589409001112

580 Galbraith, R.F., Roberts, R.G. \& Yoshida, H. 2005. Error variation in OSL palaeodose estimates from single aliquots of quartz: a factorial experiment. Radiation Measurements 39, 289-

Gallup, C.D., Cheng, H., Taylor, F.W., Edwards, R.L. 2002. Direct determination of the timing 307.

585

586

587 of sea level change during Termination II. Science 295, 310-313

Goedhart, M. 2007. Seismicity along the southern Cape Fold Belt, South Africa, association with geological structures, and early Holocene reactivation of the Kango Fault. Quaternary International 167-168, 142.

Hearty, P.J., Hollin, J.T., Neumann, A.C., O’Leary, M.J., McCulloch, M. 2007. Global sea-level fluctations during the Last Interglaciation (MIS 5e). Quaternary Science Reviews 26, 2090-2112

Hendey, Q.B., Volman, T.P. 1986. Last interglacial sea-levels and coastal caves in the Cape Province, South Africa. Quaternary Research 25, 189-98

Illenberger, W.K., 1996. The geomorphic evolution of the Wilderness dune cordons, South Africa. Quaternary International, 33, 11-20.

Jacobs, Z., Wintle, A.G. \& Duller, G.A.T. 2003. Optical dating of dune sand from Blombos Cave, South Africa: I-multiple grain data. Journal of Human Evolution 44, 599-612

Kaufman, A., Broecker, W.S., Ku, T.L., Thurber, D.L. 1971. The status of U-series methods of mollusk dating. Geochimica et Cosmochimica Acta 35, 1155-1183

Kaufman, D.S. and Manley, W. F., 1998. A new procedure for determining DL amino acid ratios in fossils using reverse phase liquid chromatography. Quaternary Science Reviews 17, 987-1000. 
Final version available at http://www.sciencedirect.com/science/article/pii/S0033589409001112

602

603

604

605

606

607

608

609

610

611

612

613

614

615

616

617

618

619

620

621

622

623

624

Kukla, G.J. 2000. The Last Interglacial. Science 287, 987-988.

Lambeck, K., Chappell, J., 2001. Sea-level change through the last glacial cycle. Science 292, $679-686$.

Lambeck, K., Esat, T.M., Potter, E.K. 2002. Links between climate and sea-levels during the past three million years. Nature 419, 199-206

Leeder, M.R., 1982. Sedimentology Process and Product. Unwin Hyman: London.

Lisiecki, L.E., Raymo, M.E. 2005. A Pliocene-Pleistocene stack of 57 globally distributed benthic $\delta^{18}$ O records. Paleoceanography VOL. 20, PA1003, doi:10.1029/2004PA001071

Malan, J.A. 1990. The stratigraphy and sedimentology of the Bredasdorp Group, southern Cape Province. Unpublished MSc Thesis, University of Cape Town.

Marean, C.W. Bar-Matthews, M., Bernatchez, J., Fisher., E., Goldberg., P., Herries, A.I.R., Jacobs., Z., Jerardino, A., Karkanas, P., Minichillo, T., Nilssen, P.J., Thompson, E., Watts, I., Williams, H.M. 2007. Early Human use of marine resources and pigment in South Africa during the Middle Pleistocene. Nature 449, 905-909.

Marker, M.E. 1987. A note on marine benches of the southern Cape. South African Journal of Geology 90, 120-124

Marker, M.E., Holmes, P.J. 2005. Landscape evolution and landscape sensitivity: the case of the southern Cape. South African Journal of Science 101, 53-60.

Marsh, R.E., Prestwich, W.V., Rink W.J, Brennan, B. J. 2003. Monte Carlo determinations of the beta dose rate to tooth enamel. Radiation Measurements 35, 609-616

Martin, A.R.H. 1962. Evidence relating to the Quaternary history of the Wilderness lakes. Transactions of the Geological Society of South Africa 65, 19-45. 
Final version available at http://www.sciencedirect.com/science/article/pii/S0033589409001112

625 Martinson, D.G., Pisias, N.G., Hays, J.D., Imbrie, J, Moore, T.C., Shackleton, N.J. 1987. Age

626 dating and the Orbital Theory of the Ice Ages - Development of a High-Resolution 0 to

627 300,000-year chronostratigraphy. Quaternary Research 27, 1-29.

628 Massari, F., and Parea, G. C. 1988. Progradational gravel beach sequences in a moderate- to 629 high-energy, microtidal marine environment. Sedimentology 35, 881-913.

630 Maud, R.R. 1968. Quaternary Geomorphology and soil formation in coastal Natal. Zeitschrift für Geomorphologie N.F. Suppl. 7, 135-165.

632 McLaren S.J. Rowe P.J. 1996. The reliability of uranium-series mollusc dates from the Western Mediterranean basin. Quaternary Science Reviews 15, 709-717.

634 Mejdahl, V. 1979 Thermoluminescence dating - Beta-dose attenuation in quartz grains.

$635 \quad$ Archaeometry 21, 61-72

636 Muhs, D.R., 2002. Evidence for the timing and duration of the Last Interglacial period from high-precision uranium-series ages of corals on tectonically stable coastlines. Quaternary Research 58, 36-40.

642 Munsell Color. 1994. Munsell Soil Color Charts. Macbeth: New Windsor.

643 Murray, A.S., Wintle A.G., 2000. Luminescence dating of quartz using an improved single-

644 aliquot regenerative-dose protocol. Radiation Measurements 32, 57-73.

645 Murray, A.S., Wintle, A.G., 2003. The single aliquot regenerative dose protocol: potential for 646 improvements in reliability. Radiation Measurements 37, 377-381. 
Final version available at http://www.sciencedirect.com/science/article/pii/S0033589409001112

647 Murray-Wallace, C. V. 2000. Quaternary coastal aminostratigraphy: Australian data in global

$648 \quad$ context. In G.A. Goodfriend (Eds), Perspectives in Amino Acid and Protein Geochemistry. Oxford University Press Oxford, UK, pp 279-300

650 Murray-Wallace, C.V. 2002. Pleistocene coastal stratigraphy, sea-level highstands and neotectonism of the southern Australian passive continental margin - a review. Journal of Quaternary Science 17, 469-489.

Murray-Wallace, C.V. Belperio, A.P. 1991. The last interglacial shoreline in Australia: a review. Quaternary Science Reviews 10, 441-461.

Non-affiliated Soil Analysis Working Committee. 1990. Handbook of Standard Soil Testing Methods for Advisory Purposes. Soil Science Society: Pretoria.

657 O’Leary, M.J., Hearty, P.J., McCulloch, M.T. 2008. Geomorphic evidence of major sea-level fluctuations during marine isotope substage-5e, Cape Cuvier, Western Australia. Geomorphology 102, 595-602

Overpeck, J.T., Otto-Bliesner, B.L., Miller, G.H. Muhs, D.R. Alley, R.B. Kiehl, J.T. 2006. Paleoclimatic Evidence for Future Ice-Sheet Instability and Rapid Sea-Level Rise.

663 Prescott, J.R., Hutton, J.T., 1994. Cosmic ray contributions to dose rates for luminescence and 664 ESR dating: large depths and long-term variations. Radiation Measurements 23, 497-500. 665 Ramsay, P.J., Cooper, J.A.G. 2002. Late Quaternary sea-level change in South Africa. Quaternary Research 57, 82-90.

667 Reddering, J.S.V. 1983. An inlet sequence produced by the migration of a small microtidal inlet against longshore drift: the Keurbooms Inlet, South Africa. Sedimentology 30, 201-218 
Final version available at http://www.sciencedirect.com/science/article/pii/S0033589409001112

Roberts, D., Berger, L.R. 1997. Last interglacial human footprints from South Africa. South African Journal of Science 93, 349-350

Roberts, D.L., Bateman, M.D., Murray-Wallace, C.V., Carr, A.S., Holmes, P.J. 2008. Last Interglacial fossil elephant trackways in coastal eolianites, Still Bay, South Africa. Palaeogeography Palaeoclimatology Palaeoecology 257, 261-279.

Roberts, D.L., Bateman, M.D., Murray-Wallace, C.V., Carr, A.S., Holmes, P.J. 2009. West Coast Dune Plumes: climate driven contrasts in dunefield morphogenesis along the western and southern South African Coasts. Palaeogeography Palaeoclimatology Palaeoecology 271, 34-48

Short, A. D. 1984. Beach and nearshore facies: Southeast Australia. Marine Geology 60, 261282.

Siesser, W.G., Rogers, J. 1970. An investigation of the suitability of four methods used in routine carbonate analysis of marine sediments. Deep Sea Research 18, 135-139.

Speed, R.C., Cheng, H. 2004. Evolution of marine terraces and sea level in the last interglacial, Cave Hill, Barbados. Geological Society of America Bulletin 116, 219-232.

Stirling, C.H., Esat, T.M., McCulloch, M.T., Lambeck, K., 1995. High-precision U-series dating of corals from Western Australia and implications for the timing and duration of the last interglacial: Earth and Planetary Science Letters 135, 115-130.

Stirling, C.H., Esat, T.M., Lambeck, K., McCulloch, M.T. 1998. Timing and duration of the Last Interglacial: evidence for a restricted interval of widespread coral reef growth. Earth and Planetary Science Letters 160, 745-762

Tankard, A.J. 1976. The Pleistocene history and coastal morphology of the Ysterfontein-Elands Bay area, Cape Province. Annals of the South African Museum 69, 73-119. 
Final version available at http://www.sciencedirect.com/science/article/pii/S0033589409001112

692 Tomazelli. L.J., Dillenburg, S.R. 2007. Sedimentary facies and stratigraphy of a last interglacial 693 coastal barrier in south Brazil. Marine Geology 244, 33-45

694 Tucker M. (ed). 1988. Techniques in Sedimentology. Blackwell: Oxford.

695 U.S. Department of Commerce, National Oceanic and Atmospheric Administration, National Geophysical Data Center, 2006. 2-minute Gridded Global Relief Data (ETOPO2v2) http://www.ngdc.noaa.gov/mgg/fliers/06mgg01.html

698 Waelbroeck, C., Labeyrie, L., Michel, E., Duplessy, J.C., McManus, J.F., Lambeck, K., Balbon, 699 E., Labracherie, M. 2002. Sea-level and deep water temperature changes derived from 700 benthonic foraminifera isotopic records: Quaternary Science Reviews 21, 295-305

701 Waelbroeck, C., Frank, N., Jouzel, J., Parrenin, F. Masson-Delmotte, V. Genty, D. 2008. Transferring radiometric dating of the last interglacial sea level highstand to marine and

704 Woodroffe, C.D., Murray-Wallace, C.V., Bryant, E.A., Brooke, B., Heijnis, H., Price, D.M. 1995. Late Quaternary sea-level highstands in the Tasman Sea - evidence from LordHowe Island. Marine Geology 125, 61-72

Woodroffe, S.A., Horton, B.P. 2005. Holocene sea-level changes in the Indo-Pacific. Journal of Asian Earth Sciences 25, 29-43.

709 Young, R.W., Bryant, E.A., Price, D. 1993. Last Interglacial sea levels on the South Coast of 710 New South Wales. Australian Geographer 24, 72-75. 